\title{
EL MINISTERIO DEL PERDÓN Y UNA APORTACIÓN A UNA RENOVADA PASTORAL DEL SACRAMENTO DE LA RECONCILIACIÓN
}

DOI: https://doi.org/10.52039/seminarios.v62i216.147

MARTÍN MUÑOZ LÓPEZ*

A MODO DE INTRODUCCIÓN: LA MISERICORDIA, UNA EXPERIENCIA ECLESIAL

Comenzamos afirmando que, al tiempo que la práctica de la misericordia es un deber de cada individuo que proclama a Jesús como Señor, es una actividad comunitaria del único Cuerpo de Cristo, que sacramentalmente tiene el deber de reintegrar al pecador en el proyecto del reino querido por el Padre desde la creación del mundo.

La Iglesia ha encontrado en la expresión sacramental la forma mejor de manifestar esta identidad con su Señor, pues en el sacramento se encuentra el lenguaje humano propio de la Encarnación (gestos y palabras), y que al mismo tiempo nos ofrece la dimensión de misterio, propia de la acción y transformación que realiza Dios en la vida del ser humano.

Todo sacramento es en sí anuncio de la misericordia del Dios compasivo. Así el bautismo al perdonar el pecado original, injerta al individuo en la dinámica de vida familiar en la Iglesia y haciendo de él testigo, como Cristo, de la dimensión del servicio que hace de cada cristiano un ser aceptable para el mundo; dígase lo mismo del sacramento de la unción y la celebración eucarística, cuyos ritos introductorios proponen un momento de perdón de los pecados para hacer de cada participante un enviado al servicio del amor y de la misericordia.

La aparición del sacramento de la reconciliación, nos dice la historia, ha sido un regalo, de por sí, fraguado en el corazón misericordioso de la madre Iglesia; quien recibiera de su Señor resucitado la autoridad para atar y desatar (cf. Mt $16,19 ; 18,18)$ y en el evangelio de Juan esta autoridad se concibe como facultad para perdonar o no los pecados (cf. Jn 20, 22-23). Aparece como segunda tabla de salvación al constatar que la limitación humana se ve vulnerada, aun después del bautismo, y ese ser humano, que pretende asociarse al proyecto de Cristo, requiere vivir nuevamente reconciliado con él y con su Cuerpo. de México.

* Licenciado en teología fundamental. Ha sido director espiritual del Seminario Conciliar 


\section{LA VIVENCIA DEL SACRAMENTO HOY}

Es importante que el día de hoy seamos capaces de reconocer las dificultades para la realización del sacramento. En general me parece que, como dice el Cardenal Kasper ${ }^{1}$, estamos frente a una crisis que se vive en general como alejamiento, sea por la mala experiencia sufrida en general por parte de algunos mayores y que aleja tajantemente; sea por el desconocimiento total que viven nuestras jóvenes generaciones y que, de la misma manera, en ocasiones influenciados por los mayores repiten los gestos del «miedo», sin tener conciencia del papel de la misericordia que aporta la práctica sacramental.

Personalmente, agregaría una tercera causa: el tiempo, y no quiero expresar simplemente lo que, como ministros, nos empeñamos para la administración del sacramento, sino la inconveniencia del tiempo que nos implica nuestro hoy. Me explico: buscando en ocasiones «la pureza» de la liturgia, en repetidas ocasiones me opuse a la realización del sacramento durante la celebración de la eucaristía, ¿cómo superponer un sacramento sobre otro? En una ocasión, sin embargo, mientras me ayudaba un hermano a la celebración de la misa, sin tener «nada que hacer», y a petición de algunas personas, me puse a confesar. Oí con atención y me parece que incluso recomendé se dieran tiempo para confesarse fuera de los horarios de la santa misa. Un señor, sin embargo, antes de ofrecerle la absolución me agradeció sentidamente el que hubiera confesado en ese momento, me dijo: «Padre, cuando he querido acercarme a la confesión, no es tiempo. Yo salgo de mi casa antes de las 6 de la mañana, horario en que la Iglesia aún no está abierta, y cuando regreso, ya muy noche y cansado, la Iglesia ya está cerrada».

El sacramento en general se vuelve también conflictivo para algunos de nosotros, porque sentimos que -y es una realidad- nos cansa, o incluso para otros no significa un ingreso monetario evidente, como lo es la ayuda que ofrecemos en la celebración eucarística o las bendiciones que realizamos con los fieles.

Por otra parte, y como nos recuerda el Santo Padre, hemos perdido el sentido del compartir comunitario. ¿Cuántas veces no escuchamos de parte de muchos católicos, incluso, la frase «yo me confieso con Dios»? Como lo afirma el papa Francisco, «si tú no eres capaz de hablar de tus errores con tu hermano, ten por seguro que no serás capaz de hablar tampoco con Dios y que acabarás confesándote con el espejo, frente a ti mismo» ${ }^{2}$. Comenzamos una situación que nos hace perder esa parte fundamental de nuestro ser social, de crecer y movernos en medio de los hermanos, introyectándonos en nuestros propios egocentrismos.

1. W. Kasper, La Misericordia. Clave del Evangelio y de la vida cristiana, Santander 2015, 162-163.

2. Papa Francisco, El nombre de Dios es Misericordia. Una conversación con Andrea Tornielli, Barcelona 2016, 42. 
En medio de todo esto, el sacramento de la reconciliación sigue presentándose como la mejor expresión de misericordia que la Iglesia, madre y maestra, puede ofrecer al mundo de hoy.

\section{LA PRÁCTICA DE LA CONFESIÓN. UNA APORTACIÓN RENOVADA}

Es necesario que la práctica de la reconciliación, como se nos ha insistido últimamente, vaya acompañada del gesto amoroso que, haciéndonos imágenes del Dios misericordioso nos devuelva a la casa paterna, como el abrazo sentido del Padre, que en su autoridad, es capaz de regresar al hijo que ha despilfarrado la herencia, para que a través de este gesto de amor, quien regresa tenga la capacidad de seguir siendo señor de sus bienes, con el gesto de alegría y regocijo que acompaña no sólo al cielo por el pecador que se arrepiente, sino aquí mismo en la tierra, el gusto de saber que podemos ser distintos frente al hermano ofendido y frente al Dios clemente (cf. Lc 15, 11-32) ${ }^{3}$.

\section{A la raíz del sacramento está el volver la mirada a Cristo Salvador, Cristo médico}

Nuestra actividad como sacerdotes y reconciliadores en una Iglesia necesitada de la misericordia de Dios, nos asemeja en primer lugar a Jesús médico, el que pasó curando toda enfermedad y dolencia (cf. Mc 4, 23). Es imposible que apartemos nuestro pensamiento de esta identidad, porque en ella se hace evidente la salvación que el Verbo Encarnado ha traído a su Iglesia.

El sacramento nos acerca desde el inicio a la misericordia de Dios, buscando no olvidar que la acción no es nuestra, sino de Dios. Que no somos dueños, sino administradores de una inmensa gracia que se nos participa.

Mirar el rostro de Jesús Salvador en el sacramento, es hacernos conscientes que ejercitamos, mejor que nadie, el ejercicio de misioneros, que no contentos con seguir el mandato del Maestro, lo anunciamos al mundo como Señor.

En el fondo es la identidad más propia de nuestro ser: llamados por el único Señor a ser testigos de su vida de resucitado y de Hijo de Dios.

\section{Perdonar en perfecta actitud materna, es la Iglesia quien perdona}

Cuando acababa de llegar a trabajar a la Basílica de Guadalupe como capellán de coro, el Canónigo José Luis Guerrero me sorprendió con una reflexión muy particular: «Si ya estás en este santuario mariano, te corresponde ahora ser madre para los demás, porque no tenemos otra misión sino la de seguir

3. Conviene aclarar que la mayoría de las ideas aquí desarrolladas, están tomadas fundamentalmente del discurso que el Papa Francisco dirigió a los «Misioneros de la Misericordia» el martes 9 de febrero, en la Sala Regia del Palacio Apostólico. 
anunciando a la Iglesia, lo que María comunicó: No tengas miedo, ¿no estoy yo aquí que soy tu madre?».

En el inicio de la audiencia papal, se comenzó también con unas palabras semejantes: «Estáis llamados a expresar la maternidad de la Iglesia. La Iglesia es madre porque siempre genera nuevos hijos en la fe; la Iglesia es madre porque nutre la fe; y la Iglesia es madre también porque ofrece el perdón de Dios, regenerando a una nueva vida, fruto de la conversión». Actitud de madre, quizá para nosotros sacerdotes, resulta un tanto complicado vernos envueltos en esta dinámica femenina de la maternidad. Sin embargo, se trata del mismo don de la paternidad-maternidad con el que el Buen Dios ha bendecido a la humanidad desde sus orígenes. Me parece que en el fondo es una vuelta a esa dinámica familiar con la que insistentemente el Papa afronta para la revaloración de la familia. Entender ésta como el lugar propio donde genera, se hace crecer y se enseña a vivir. Los padres, generadores de vida, no se pueden entender como sólo los que dan origen, sino los que, desde su experiencia, acompañan el crecimiento hasta dejar, sin abandonar, la vida de los hijos que han comenzado a caminar por sí solos. De la misma manera, me parece que en general la práctica del sacramento no puede reducirse al momento del encuentro en el confesionario. El sacerdote debería seguir con su oración, y sin violar el sigilo, el acompañamiento que, desde un corazón de padre, puede dar a los suyos.

El corazón de madre, es un corazón acostumbrado a aceptar las limitaciones, porque ha podido aceptar las limitaciones propias, y amar, simplemente, para desde ahí acompañar el crecimiento no sólo espiritual, sino aún el psicológico, que exige una aceptación de sí mismo y el suficiente esfuerzo para procurar ser mejores.

\section{Aprendiendo a leer más allá de lo verbal: El lenguaje del gesto}

Un tercer aporte es el de aprender a leer los gestos del pecador. Como decía el papa Francisco, «Si alguien viene a confesarse es porque siente que hay algo que debería quitarse pero que tal vez no logra decirlo, pero tú comprendes... y está bien, lo dice así, con el gesto de venir» ${ }^{4}$. En mi particular modo de ver, se trata, por una parte, de agudizar los sentidos como el 'padre', para interpretar y buscar no solamente en la limitación de las palabras, lo que ocurre en el corazón del que busca arrepentido a su Señor. Es salir al encuentro del otro, entendiendo, aun antes de que exprese que sólo busca ser tratado como uno más de los jornaleros de casa, la aceptación reposada y real del individuo en toda su dimensión personal. Me parece que en este punto encontramos la clave misma de la misericordia (miserere - corda, acercarse a la miseria desde el corazón). El corazón está disponible a realizar una lectura que va más allá de las palabras,

4. Ibid. 
a comprender las razones más profundas de la distancia y a compartir desde la propia experiencia el don de la reconciliación divina. Leer más allá de lo verbal, implicaría así un gesto del todo trascendente, que es el silencio que escucha. No es posible asistir al evento reconciliatorio sin la escucha atenta y esto es no cargar al otro de nuestras propias pre-disposiciones o pre-juicios. Es comenzar a tener una mirada contemplativa, como la del Padre, como la de Jesús, que tienen esperanza y confianza en la transformación de vida de los que se acercan a ellos: «No temas, desde hoy serás pescador de hombres» (LC 5,10$)$.

El lenguaje del gesto es acostumbrar a los ministros a tener abiertos no solamente los oídos, sino todo nuestro ser y comprender que al tiempo que a Dios se le ama con toda el alma, con toda la mente, con todo el ser, de la misma manera se ejerce este ministerio hacia el hermano, reverenciándolo como Dios ha hecho con cada uno al enviarnos a su propio Hijo.

Para comprender el signo de la vergüenza: La desnudez y el revestimiento

En el texto del Génesis aparece un pasaje en la vida de Noé, donde éste, después del diluvio, cultiva sus vides y se embriaga (cf. Gn 9, 20-27). Entra a su tienda y se desnuda. Cam, uno de sus hijos lo ve y sale a contar a sus hermanos Sem y Jafet, estos últimos entran a la tienda con un manto, de espaldas para no ver la desnudez del padre y cubrirlo.

En esta narración se nos hace comprender el signo de la vergüenza, como la experiencia de Adán al descubrirse desnudo ante el Creador, es decir, la comprensión de la propia limitación como experiencia de distancia frente a Dios. La vergüenza, generalmente se presenta como esa actitud que nos aleja para enfrentar al mundo, que nos hace frágiles ante la grandeza de Dios y nos lleva a ocultar el rostro. Es comprender que el ser humano que se acerca al sacramento lleva consigo la condición de alejado frente a Dios y frente a los hermanos.

Frente a la desnudez de Noé, se presenta contrastante la actitud de sus hijos Sem y Jafet, quienes tomando el manto cubren al padre devolviéndole su dignidad. Más adelante, el nuevo testamento nos recordará en la parábola del Padre Misericordioso cómo ordena que el hijo menor sea revestido al llegar a la casa paterna lleno de vergüenza.

Esta es mejor que nada, la actitud sacerdotal, que, comprendiendo el alejamiento, nos encontramos con la gracia de revestir o devolver al hermano la capacidad para sentirse orgulloso de sí mismo, enfrentar al mundo y presentarse ante Dios sin el desconocimiento de sí, sino en la categoría de vivir y actuar como hijo.

De cuántas cosas toca revestir a nuestra humanidad desnuda de sentido y comprensión de sí misma, sin escándalos, sino con el tacto suficiente que respeta la indignidad con la que se percibe el pecador, para hacerlo redescubrir su dignidad de hijo. 
Hacer volver a la casa, al seno familiar, con la fuerza de la compasión

El único camino posible que nos hace recuperar nuestra propia dignidad no es la condena, sino la compasión.

Resulta muy querida al Papa la imagen de la pecadora que sorprendida en flagrante adulterio es conducida ante Jesús para ser lapidada ${ }^{5}$. Frente a la severidad de sus acusadores, se impone la compasión de Jesús, quien misericordiosamente se inclina, con ella, para escribir en el suelo, y levantándose confronta a los acusadores que arrojen la primera piedra quien esté libre de pecado.

La compasión, padecer-con, se vuelve el momento de identidad profunda del pecador y el confesor, porque en la miseria del otro se puede descubrir y afrontar mejor la propia miseria. Dios no busca la condena, sino el restablecimiento de nuestra vida de acuerdo a su proyecto. $Y$ de la misma manera que podemos entender que Dios nos ha conducido a su herencia, de la misma manera buscamos hacer partícipes de la herencia del padre a quienes se acercan al sacramento.

Es el modo de obrar totalmente divino de Jesús, que no busca afirmar su autoridad desde la exigencia del cumplimiento de la ley, sino desde la pertenencia al Padre como tal, porque busca la vida de quienes nos hemos privado de ella por nuestra errónea manera de ser.

Sin «abaratamiento» del sacramento, sino como un ser íntegro. Verdadero hijo de Dios

Finalmente, y un asunto poco atendido por los medios de comunicación al hablar en estos días de la misericordia que el Papa nos invita a vivir, es la búsqueda de la transformación vital.

A mí me gusta insistir sobre el repetido slogan «Dios me quiere como soy», al que se nos olvida añadir: "pero me quiere mucho mejor».

Dietrich Bonhöeffer, en su obra El precio de la gracia. El seguimiento ${ }^{6}$, nos advierte sobre el abaratamiento de la gracia. Un concepto donde nos invita a reconocer que la justificación del pecado y no del pecador, es un proceso que algunos sacerdotes ejercitamos en deterioro de la búsqueda del Reino nuevo.

En nuestros días asistimos, especialmente por algunos medios de comunicación, al abaratamiento de esta gracia, cuando escuchamos frases como: «el Papa ya dio permiso de comulgar a los divorciados vueltos a casar», o «en este año se permite el aborto porque todos los sacerdotes pueden perdonarlo».

Si como dijimos anteriormente, la Iglesia, en su actitud de madre busca la aceptación y desarrollo armónico de sus hijos, el sacramento, en su parte más sacramental no puede excluir la penitencia o reparación de la falta. Que no es

5. Cf. Papa Francisco, El nombre de Dios es Misericordia, Barcelona 2016, 74-75.

6. D. Bonhoeffer, El precio de la gracia. El seguimiento, Salamanca ${ }^{7} 2004$. 
otra cosa, sino la búsqueda concreta de la aceptación de vida nueva por el amor con que el Padre me acepta y ama, hasta llevarme a tener experiencia de vida nueva. No se trata de pensar que ahora «estamos de oferta en el perdón de los pecados», sino que de manera especial, los pastores, aceptamos el tiempo de gracia para que el pecador vuelva a Dios, para que nuestras oraciones y expresiones de compasión hagan mella en el corazón del hombre que busca contemplar sin vergüenza el rostro de Dios.

Se trata de retomar, en esta manera de visualizar pastoralmente el sacramento, de hacer nuevo el proyecto original del Padre de compartir con sus hijos el Reino preparado para nosotros desde la creación del mundo. 